\title{
Helicobacter pylori-epithelial cell interactions: From adhesion to apoptosis
}

Nicola L Jones MD FRCPC, Philip M Sherman MD FRCPC

\begin{abstract}
NL Jones, PM Sherman. Helicobacter pylori-epithelial cell interactions: From adhesion to apoptosis. Can J Gastroenterol 1999;13(7):563-566. Studies suggest that host cell signal transduction cascades are manipulated during infection with microbes, including the gastric pathogen Helicobacter pylori. Several putative adhesins have been proposed to mediate the attachment of $H$ pylori to gastric epithelial cells. Following bacterial binding, a series of signalling pathways are activated in the infected gastric epithelial cell. These signals include both cytoplasmic (such as vacuolization, tyrosine phosphorylation and elevation of cytosolic calcium) and nuclear (proliferation, apoptosis and chemokine transcription) events. Research aimed at elucidating the interactions that occur between the host cell and the bacterium during infection should improve the limited knowledge of disease pathogenesis.
\end{abstract}

Key Words: Adhesion; Apoptosis; Helicobacter pylori; Signal transduction; Vacuolation

\section{Les interactions entre les cellules épithéliales et Helicobacter pylori : de l'adhésion à l'apoptose}

RÉSUMÉ : Des études laissent à penser que les cascades du signal de transduction de la cellule hôte sont manipulées pendant une infection par des microbes, y compris le pathogène gastrique Helicobacter pylori. Plusieurs mécanismes putatifs d'adhésion ont été proposés pour médier l'adhésion de H. pylori aux cellules épithéliales gastriques. À la suite de l'adhésion bactérienne, une série de voies de signalisation sont activées dans la cellule épithéliale gastrique infectée. Ces signaux comprennent à la fois des événements cytoplasmiques (tels que la vacuolisation, la phosphorylation de la tyrosine et l'augmentation du calcium cytosolique) et nucléaires (prolifération, apoptose et transcription des chimiokines). Les recherches visant à élucider les interactions qui surviennent entre la cellule hôte et la bactérie pendant une infection devraient accroître les connaissances sur la pathogénie de la maladie.
A new research field termed 'cellular microbiology' merges the disciplines of cellular biology and microbiology and is yielding important new information (1). Investigators in this discipline study the cross talk that occurs between pathogens, or their products, and the target eukaryotic cell to advance understanding of both disease pathophysiology and cell biology (2).

The consequences of the interactions between the gastric pathogen Helicobacter pylori and epithelial cells during infection of humans include a manipulation of host cell signalling that is likely to play a role in disease pathogenesis. Following adhesion, cytoplasmic signal transduction pathways, vacuolar trafficking and nuclear signalling events are exploited by the bacterium. In addition to enhancing our knowledge of how bacterial pathogens interact with host cells to mediate disease, the investigation of these virulence factors provides novel tools to study aspects of cellular biology.

\section{MICROBIAL ADHESION AND THE INDUCTION OF EUKARYOTIC CELL SIGNAL TRANSDUCTION PATHWAYS}

H pylori exhibits tropism for gastric epithelial cells (3). During infection, the bacteria binds specifically to gastric epithelial cells lining the stomach or in areas of gastric metaplasia. The underlying mechanisms responsible for this tissue tropism remain unclear but likely are related to specific bacterial adhesins. The precise adhesin(s) responsible for $\mathrm{H}$ pylori binding to gastric epithelial cells are unknown. However, a number of putative attachment factors for the organism have been investigated and are discussed (Table 1).

A role for microenvironmental $\mathrm{pH}$ in the modification of bacterial binding has been suggested. Huesca et al (4) demonstrated that a brief period of acid shock altered $H$ pylori binding specificity with an increase in bacterial adherence to sulfogalactosyl ceramide as assessed by using thin-layer chromatography overlay. This effect was abro-

Division of Gastroenterology/Nutrition, Research Institute, The Hospital for Sick Children, University of Toronto, Toronto, Ontario

Correspondence: Dr NL Jones, Division of Gastroenterology, Room 8409, The Hospital for Sick Children, 555 University Avenue, Toronto, Ontario M5G 1X8. Telephone 416-813-6182, fax 416-813-6531, e-mail njones@sickkids.on.ca 
TABLE 1

Putative adhesins of Helicobacter pylori

\begin{tabular}{lc}
\hline Adhesin & Reference \\
\hline Flagellin & 3 \\
Lipopolysaccharide & 50 \\
Exoenzyme H & 51 \\
Heat shock proteins & 4 \\
Urease & 6,7 \\
Hemagglutinins & 52 \\
BabA (Le ${ }^{\text {b binding adhesin) }}$ & 10 \\
Outer membrane proteins & 12 \\
\hline
\end{tabular}

gated by incubation with inhibitors of protein synthesis or antiheat shock protein antibodies, suggesting a possible role of heat shock proteins in mediating adhesion. In support of a role for $\mathrm{pH}$ in altering adherence in vitro, Corthesy-Theulaz et al (5) identified an increase in $H$ pylori binding to the intestinal T84 cell line at $\mathrm{pH} 5.4$ compared with $\mathrm{pH}$ 7.4.

Although urease previously was proposed to mediate bacterial attachment (6), more recent studies suggest that this surface-exposed enzyme does not play a role in the adhesion of $\mathrm{H}$ pylori to gastric epithelia. Comparison of binding between an isogenic urease-negative mutant and the parent strain to either primary gastric epithelial cells or a gastric epithelial cell line in vitro showed no demonstrable difference (7). Similarly, a lack of correlation between the expression of hemagglutinins and $H$ pylori binding in vitro suggests that hemagglutinins do not play a major role in adherence (8).

In situ studies suggest that the fucosylated blood group antigen Lewis b mediates binding of $H$ pylori to gastric epithelial cells (9). The putative $H$ pylori adhesin, which binds to the Lewis b blood group antigen, has been identified. Using a receptor activity-directed affinity tagging method, Ilver et al (10) purified and cloned blood group antigen-binding adhe$\sin (\mathrm{BabA})$. The presence of the $\mathrm{Le}^{\mathrm{b}}$ binding phenotype was associated with the presence of the cag pathogenicity island. The possible role of the pathogenicity island in regulating binding to $\mathrm{Le}^{\mathrm{b}}$ is unclear because deletion of the entire pathogenicity island did not reduce binding to the $\mathrm{Le}^{\mathrm{b}}$ antigen in vitro. The importance of $\mathrm{Le}^{\mathrm{b}}$ as a receptor for $\mathrm{H}$ pylori has recently been questioned because in vitro studies demonstrate that adhesion of $\mathrm{H}$ pylori to isolated human gastric epithelial cells is independent of the expression of Lewis antigens (11).

Although the precise factors mediating $H$ pylori adherence are unclear, it is likely that multiple adhesins are involved. The recent sequencing of the entire genome of one $\mathrm{H}$ pylori strain allowed the identification of the presence of a large proportion of outer membrane proteins and lipoproteins, which may serve as putative adhesins (12). It is also possible that the outer membrane proteins are involved in antigenic variation, leading to immune evasion and persistence of infection by the bacterium (13).

In addition to allowing binding to specific receptors on host gastric epithelial cells, adhesins can mediate a cascade of signals within the eukaryotic cell. Following intimate ad- herence of H pylori to epithelial cells in vitro, there is an elevation in the second messenger inositol trisphosphate (IP3) $(14,15)$. It is uncertain whether bacterial adherence is necessary for activation of this signal transduction pathway because poorly adherent or nonadherent strains also generate IP3 production in infected epithelial cells (15).

The activation of IP3 signalling is similar to the cascade of events associated with infection with the gastrointestinal pathogen enteropathogenic Escherichia coli (EPEC) (14). EPEC infection of eukaryotic cells induces the elevation of inositol phosphate, calcium flux and tyrosine phosphorylation of a $90 \mathrm{kDa}$ protein in association with rearrangements of the cytoskeleton underneath the adherent bacteria (known as the attaching and effacing lesion) (16). However, it remains controversial whether tyrosine phosphorylation of host proteins and alteration of the cytoskeleton to form the attaching and effacing lesion occur during $\mathrm{H}$ pylori infection. Smoot et al (17) and Segal et al (18) identified F-actin accumulation and pedestal formation in gastric epithelial cells infected with $H$ pylori in association with tyrosine phosphorylation of two host proteins differing in size from the $90 \mathrm{kDa}$ phosphorylated protein during EPEC infection. Isogenic mutants generated in the cag pathogenicity island abrogated host cell phosphorylation (19). In contrast, Dytoc et al (14) and Pucciarelli et al (15) observed the effacement of microvilli in infected epithelial cells in the absence of redistribution of host cell cytoskeletal elements.

The significance of bacterial adhesion in mediating disease was recently demonstrated in a murine model (20). $\mathrm{H}$ pylori-infected transgenic mice genetically engineered to express the putative receptor $\mathrm{Le}^{\mathrm{b}}$ in the gastric pit and mucous cells showed an altered pattern of bacterial adhesion and disease manifestations compared with normal littermates. Both groups of mice displayed an equivalent degree of colonization. However, bacteria bound to the mucous layer in normal mice, whereas bacteria adhered to both the mucous layer and the pit, and surface epithelial cells of Le ${ }^{b}$ expressing mice. A higher proportion of transgenic mice developed more severe gastritis with the presence of mucosalassociated lymphoid tissue ( $53 \%$ versus $20 \%, \mathrm{P}<0.05)$. In addition, parietal cell autoantibodies were detected more frequently in the transgenic mice ( $87 \%$ versus $26 \%$ ) at 16 weeks after infection. The presence of autoantibodies was associated with more pronounced reactive atypia and parietal cell loss. Although the factors involved in adhesionmediated injury have yet to be determined, these studies highlight the importance of bacterial binding in disease pathogenesis.

\section{VACUOLATING CYTOTOXIN-STIMULATED SIGNAL TRANSDUCTION}

Approximately half of all $\mathrm{H}$ pylori strains produce a cytotoxin, referred to as $\mathrm{VacA}$, which induces the vacuolation of epithelial cells in vitro (21). Recent evidence suggests that allelic variation of vacA determines the cytotoxin-producing phenotype of a given strain (22). The gene encoding the vacuolating cytotoxin $(\mathrm{vacA})$ is present in all $\mathrm{H}$ pylori strains 
outside the cag pathogenicity island. However, only strains with the s1, m1 alleles express toxin protein (22).

Elegant studies using $\mathrm{VacA}$ as a probe are defining the cellular mechanisms involved in cytotoxin-mediated vacuolation. Papini et al (23) identified markers of the late endosomal compartments, including the vacuolar-ATPase and the GTPase rab7 on the vacuolar membranes. In addition, cells overexpressing activated rab7 stimulate vacuole formation when exposed to VacA (24). In contrast, vacuole formation is inhibited in cells expressing a dominant negative mutant rab7. These findings indicate that the toxin-induced disruption in endocytic trafficking occurs at a late stage and is mediated by rab7.

Lysosomal markers have also been identified on the vacuolar membranes (25), suggesting that the vacuoles are comprised of a mixed endosomal-lysosomal compartment. In support of this contention, processing and sorting of proteins normally targeted to the lysosome are altered by VacA (26). A recent study suggests that one possible sequelae of $\mathrm{VacA}$ altered organellar trafficking includes the interruption of the li-dependent pathway of antigen presentation by newly synthesized major histocompatibility complex (MHC) class II molecules (27).

In addition to vacuole formation, the toxin stimulates host cell signal transduction pathways in vitro, including stimulation of inositol phosphates and cytosolic free calcium (28). Increases in adenosine $3^{\prime} 5^{\prime}$-cyclic monophosphate in association with phosphorylation of $31 \mathrm{kDa}$ and $22 \mathrm{kDa}$ proteins are present following eukaryotic cell exposure to VacA (28).

\section{H PYLORI-MEDIATED NUCLEAR SIGNALLING AND APOPTOSIS}

$H$ pylori infection of gastric epithelial cell lines causes activation and nuclear translocation of the transcription factor nuclear factor-kappaB (NF-kB) that results in increased transcription of chemokines, including interleukin-8 (IL-8) $(29,30)$. Studies of $H$ pylori-infected human gastric biopsy specimens confirm both an enhanced IL-8 production (31) and activation of NF-KB (29). Using transfection experiments with reporter gene constructs, Aihara et al (30) demonstrated that NF- $\kappa \mathrm{B}$ and activator protein-1 binding to the IL-8 promotor region both upregulate production of IL-8 (30). Recent studies suggest that direct bacterial contact is needed to induce gastric epithelial cell IL-8 secretion (32). Mutational analysis provides evidence for a role of picB (named for 'promote the induction of cytokines', also known as cagE) in mediating IL-8 secretion $(33,34)$. It is unclear whether picB directly upregulates IL- 8 or is involved in the export or secretion of another activator.

In addition to NF- $\kappa \mathrm{B}$ activation, $H$ pylori infection alters the gastric epithelial cell cycle, enhancing both proliferation and programmed cell death of gastric epithelial cells $(35,36)$. These changes in cell turnover are identified in both $\mathrm{H}$ pylori-infected children (Table 2) (37) and adults (38). Studies have identified enhanced expression of the tumour suppressor p53 during $H$ pylori infection both in vitro (39) and in vivo (37). Enhanced expression of the proapoptotic protein
TABLE 2

Cell cycle alterations during $\boldsymbol{H}$ pylori infection in children

\begin{tabular}{lcccl}
\hline & Control & $\begin{array}{c}\text { H pylori- } \\
\text { negative } \\
\text { gastritis }\end{array}$ & $\begin{array}{c}\text { H pylori- } \\
\text { positive } \\
\text { gastritis }\end{array}$ & \multicolumn{1}{c}{ P } \\
\hline Apoptotic index & $40 \pm 10$ & $50 \pm 10$ & $120 \pm 10$ & $<0.005$ \\
Proliferative index & $13.7 \pm 3.1$ & $18.9 \pm 2.8$ & $32.4 \pm 3.5$ & $<0.01$ \\
p53 expression & $3.7 \pm 0.9$ & $2.4 \pm 0.9$ & $19.9 \pm 3.7$ & $<0.005$ \\
\hline
\end{tabular}

Results are expressed as means \pm SE. Data from reference 37

Bak is also seen during $H$ pylori infection (40). These studies suggest that $H$ pylori may activate the apoptotic pathway by more than one mechanism.

In vitro experiments indicate that the bacterium can directly induce apoptosis $(41,42)$ and that bacterial-epithelial cell contact is required (40). The exact bacterial factors involved are an area of intense investigation. Fan et al (43) reported that bacterial binding to gastric epithelial cells that express MHC class II is capable of inducing apoptosis. Studies in $\mathrm{H}$ pylori-infected adults suggest that the presence of infection with a CagA-positive strain is associated with an enhanced proliferative rate of gastric epithelial cells in the absence of an accompanying increase in apoptosis (44). In vitro studies provide conflicting results regarding the role of CagA in abrogating apoptosis (45).

In addition to a direct effect of the bacterium, recent studies implicate a role of immune-mediated apoptosis of gastric epithelial cells. Among H pylori-infected children, gastric epithelial cell apoptosis returned to baseline only following both eradication of the bacterium and resolution of gastritis (37). One mechanism by which immune cells trigger apoptosis of target cells occurs through binding of the Fas receptor to the Fas ligand (46). In vitro experiments suggest that Fas receptor expression is upregulated on gastric epithelial cells during $H$ pylori infection (41). In addition, Rudi et al (47) detected an increase in Fas receptor-expressing gastric epithelial cells and Fas ligand-expressing infiltrating cells in gastric biopsy specimens obtained from $\mathrm{H}$ pylori-infected adults.

In vivo studies using animal models of helicobacter infection should clarify the factors involved in the observed alterations in cell turnover in infected humans. For instance, in a recent study of three inbred mouse strains (BALB/c, $\mathrm{C} 3 \mathrm{H} / \mathrm{HeJ}$ and $\mathrm{C} 57 \mathrm{BL} / 6)$, Helicobacter felis infection increased gastric cell apoptosis only in the C57BL/6 strain (48). The authors suggested that one explanation for the observed findings is a lack of secretory phospholipase $\mathrm{A}_{2}$ (recently indentified as the locus responsible for influencing polyposis in the Min mouse (49) in the C57BL/6 strain.

\section{CONCLUSIONS}

Evidence suggests that $H$ pylori can be included among the growing list of microbes that alter host signal transduction cascades during infection. The studies summarized in this review document that the bacterium, and its products, mediate both cytoplasmic and nuclear signalling events. Investiga- 
tion of the interactions between the bacterium and the host cell should elucidate the mechanisms involved in disease pathogenesis.

\section{REFERENCES}

1. Cossart P, Boquet P, Normark S, Rappouli R. Cellular microbiology emerging. Science 1996;271:315-6.

2. Fasano A. Cellular microbiology: How enteric pathogens socialize with their intestinal host. J Pediatr Gastroenterol Nutr 1998;26:520-32.

3. Clyne M, Drumm B. Adherence of Helicobacter pylori to the gastric mucosa. Can J Gastroenterol 1997;11:243-8.

4. Huesca M, Borgia S, Hoffman P, Lingwood CA. Acidic $\mathrm{pH}$ changes receptor binding specificity of Helicobacter pylori: A binary adhesion model in which surface heat shock proteins mediate sulfatide recognition in gastric colonization. Infect Immun 1996;64:2643-8.

5. Corthesy-Theulaz I, Portac N, Pringault E, et al. Adhesion of Helicobacter pylori to polarized T84 human intestinal cell monolayers is $\mathrm{pH}$ dependent. Infect Immun 1996;64:3827-32.

6. Fauchere JL, Blaser MJ. Adherence of Helicobacter pylori cells and their surface components to HeLa cell membranes. Microb Pathog 1990;427-39.

7. Clyne M, Drumm B. The urease enzyme of Helicobacter pylori does not function as an adhesin. Infect Immun 1996;64:2817-20.

8. Clyne M, Drumm B. Adherence of Helicobacter pylori to primary human gastrointestinal cells. Infect Immun 1993;61:4051-7.

9. Falk PG, Bry L, Holgersson J, Gordon JI. Expression of a human $\alpha-1,3 / 4$-fucosyltransferase in the pit cell lineage of FVB/N mouse stomach results in production of $\mathrm{Le}^{b}$-containing glycoconjugates: a potential transgenic mouse model for studying Helicobacter pylori infection. Proc Natl Acad Sci 1995;92:1515-9.

10. Ilver D, Arnqvist A, Ogren J, et al. Helicobacter pylori adhesin binding fucosylated histo-blood group antigens revealed by retagging. Science 1998;279:373-7.

11. Clyne M, Drumm B. Absence of effect of Lewis A and Lewis B expression on adherence of Helicobacter pylori to human gastric cells. Gastroenterology 1997;113:72-80.

12. Tomb JF, White O, Kerlavage AR, et al. The complete genome sequence of the gastric pathogen Helicobacter pylori. Nature 1997;388:539-47.

13. Dorrell N, Wren BW. From genes to genome biology: a new era in Helicobacter pylori research. Gut 1998;42:451-3.

14. Dytoc M, Gold B, Louie M, et al. Comparison of Helicobacter pylori and attaching-effacing Escherichia coli adhesion to eukaryotic cells. Infect Immun 1993;61:448-56.

15. Pucciarelli MG, Ruschkowski S, Trust TJ, Finlay BB. Helicobacter pylori induces an increase in inositol phosphates in cultured epithelial cells. FEMS Microbiol Lett 1995;129:293-300.

16. Nataro JP, Kaper JB. Diarrheagenic Escherichia coli. Clin Microbiol Rev 1998;11:142-201.

17. Smoot DT, Resau JH, Naab T, et al. Adherence of Helicobacter pylori to cultured human gastric epithelial cells. Infect Immun 1993;61:350-5.

18. Segal ED, Falkow S, Tompkins LS. Helicobacter pylori attachment to gastric cells induces cytoskeletal rearrangements and tyrosine phosphorylation of host cell proteins. Proc Natl Acad Sci USA 1996;93:1259-64.

19. Segal ED, Lange C, Covacci A, Tompkins LS, Falkow S. Induction of host signal transduction pathways by Helicobacter pylori. Proc Natl Acad Sci USA 1997;94:7597-9.

20. Guruge JL, Falk PG, Lorenz RG, et al. Epithelial attachment alters the outcome of Helicobacter pylori infection. Proc Natl Acad Sci USA 1998;95:3925-30.

21. Cover TL. The vacuolating cytotoxin of Helicobacter pylori. Mol Microbiol 1996;20:241-6

22. Atherton JC, Peek RM, Tham KT, Cover TL, Blaser MJ. Clinical and pathological importance of heterogeneity in vacA, the vacuolating cytotoxin gene of Helicobacter pylori. Gastroenterology 1997;112:92-9.

23. Papini E, de Bernard M, Milia E, et al. Cellular vacuoles induced by Helicobacter pylori originate from late endosomal compartments. Proc Natl Acad Sci USA 1994;91:9720-4.

24. Papini E, Satin B, Bucci C, et al. The small GTP binding protein rab7 is essential for cellular vacuolation induced by Helicobacter pylori cytotoxin. EMBO J 1997;16:15-24.

25. Molinari M, Galli C, Norais N, et al. Vacuoles induced by Helicobacter pylori toxin contain both late endosomal and lysosomal markers. J Biol Chem 1997;272:25339-44.

26. Satin B, Norais N, Telford J, et al. Effect of Helicobacter pylori vacuolating toxin on maturation and extracellular release of procathepsin D and on epidermal growth factor degradation. J Biol Chem 1997;272:25022-8.

27. Molinari M, Salio M, Galli C, et al. Selective inhibition of the li-dependent antigen presentation by Helicobacter pylori toxin VacA. J Exp Med 1998;187:135-40.

28. Chan EC, Chen KT, Lin YL. Vacuolating toxin from Helicobacter pylori activates cellular signaling and pepsinogen secretion in human gastric adenocarcinoma cells. FEBS Lett 1996;399:127-30.

29. Keates S, Hitti YS, Upton M, Kelly CP. Helicobacter pylori infection activates NF- $\mathrm{KB}$ in gastric epithelial cells. Gastroenterology 1997;113:1099-109.

30. Aihara M, Tsuchimoto D, Takizawa $\mathrm{H}$, et al. Mechanisms involved in Helicobacter pylori-induced interleukin-8 production by a gastric cancer cell line, MKN45. Infect Immun 1997;65:3218-24.

31. Crabtree JE, Wyatt JI, Trejdosiewicz LK, et al. Interleukin-8 expression in Helicobacter pylori infected, normal, and neoplastic gastroduodenal mucosa. J Clin Pathol 1994:47:61-6.

32. Rieder G, Hatz RA, Moran AP, Walz A, Stolte M, Enders G. Role of adherence in interleukin-8 induction in Helicobacter pylori-associated gastritis. Infect Immun 1997;65:3622-30.

33. Tummuru MK, Sharma SA, Blaser MJ. Helicobacter pylori picB, a homologue of the Bordetella pertussis toxin secretion protein, is required for induction of IL-8 in gastric epithelial cells. Mol Microbiol 1995; 18:867-76.

34. Censini S, Lange C, Xiang Z, et al. cag, a pathogenicity island of Helicobacter pylori, encodes type-I specific and disease-associated virulence factors. Proc Natl Acad Sci USA 1996;93:14648-53.

35. Moss SF, Calam J, Agarwal B, Wang S, Holt PR. Induction of gastric eptithelial apoptosis by Helicobacter pylori. Gut 1996;38:498-501.

36. Brenes F, Ruiz B, Correa P, et al. Helicobacter pylori causes hyperproliferation of the gastric epithelium. Pre- and post-eradication indices of proliferating cell nuclear antigen. Am J Gastroenterol 1993;88:1870-5.

37. Jones NL, Shannon PT, Cutz E, Yeger H, Sherman PM. Increase in proliferation and apoptosis of gastric epithelial cells early in the natural history of Helicobacter pylori infection. Am J Pathol 1997;151:1695-703.

38. Mannick EE, Bravo LE, Zarama G, et al. Inducible nitric oxide synthase, nitrotyrosine, and apoptosis in Helicobacter pylori gastritis: effect of antibiotics and antioxidants. Cancer Res 1996;56:3238-43.

39. Ashktorab H, Allen CR, Reeves B, Smoot DT. Regulation of apoptosis by differential expression of wafl, $p 53$ and bcl-2 in gastric cells exposed to H pylori. Gastroenterology 1997;112:A535. (Abst)

40. Chen G, Sordillo EM, Ramey WG, et al. Apoptosis in gastric epithelial cells is induced by Helicobacter pylori and accompanied by increased expression of Bak. Biochem Biophys Res Comm 1997;239:626-32.

41. Jones NL, Day AS, Jennings H, Sherman PM. Helicobacter pylori induces gastric epithelial cell apoptosis in association with increased Fas receptor expression. Infect Immun 1999;67:4237-42.

42. Wagner S, Beil W, Westermann J, et al. Regulation of gastric epithelial cell growth by Helicobacter pylori: Evidence for a major role of apoptosis. Gastroenterology 1997;113:1836-47.

43. Fan XJ, Crowe SE, Behar S, et al. The effect of Class II major histocompatability complex expression on adherence of Helicobacter pylori and induction of apoptosis in gastric epithelial cells: A mechanism for T helper cell type 1-mediated damage. J Exp Med 1998; 187:1659-69.

44. Peek RM, Moss SF, Tham KT, et al. Helicobacter pylori cagA+ strains and dissociation of gastric epithelial cell proliferation from apoptosis. J Natl Cancer Inst 1997;89:863-8.

45. Wagner S, Wingbermuhle D, Beil W, et al. Significance of H. pylori CagA and VacA genotypes on apoptosis of gastric epithelial cells. Gastroenterology 1998;114:A326. (Abst)

46. Fraser A, Evan G. A license to kill. Cell 1996;85:781-4.

47. Rudi J, Kuck D, Strand S, et al. Involvement of the CD95 (APO-1/Fas) receptor and ligand system in Helicobacter pylori-induced gastric epithelial cell apoptosis. J Clin Invest 1998;102:1506-14.

48. Wang TC, Goldenring JR, Dangler C, et al. Mice lacking secretory phospholipase $\mathrm{A}_{2}$ show altered apoptosis and differentiation with Helicobacter felis infection. Gastroenterology 1998;114:675-89.

49. MacPhee M, Chepenik KP, Liddell RA, Nelson KK, Siracusa LD, Buchberg AM. The secretory phospholipase $\mathrm{A}_{2}$ gene is a candidate for the Mom1 locus, a major modifier of $\mathrm{APC}^{\mathrm{min}}$-induced intestinal neoplasia. Cell 1995;81:957-66.

50. Valkonen $\mathrm{KH}$, Wadstrom T, Moran AP. Identification of the $\mathrm{N}$-acetylneuraminyllactose-specific laminin-binding protein of Helicobacter pylori. Infect Immun 1997;65:916-23.

51. Lingwood CA, Huesca M, Kuksis A. The glycerolipid receptor for Helicobacter pylori (and exoenzyme S) is phosphatidylethanolamine. Infect Immun 1992;60:2470-4.

52. Evans DG, Evans DJ, Moulds JJ, Graham DY. N-acetylneuraminyl lactose-binding fibrillar hemagglutinin of Campylobacter pylori: a putative colonization factor antigen. Infect Immun 1988;56:2896-906. 


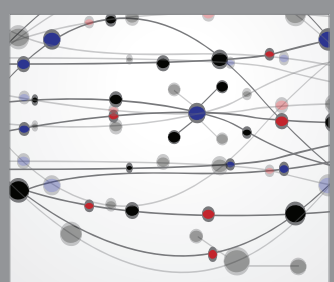

The Scientific World Journal
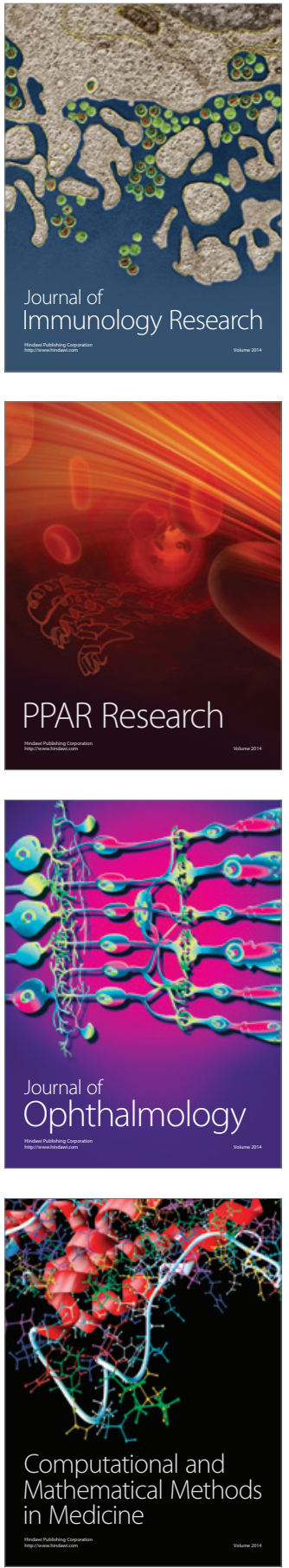

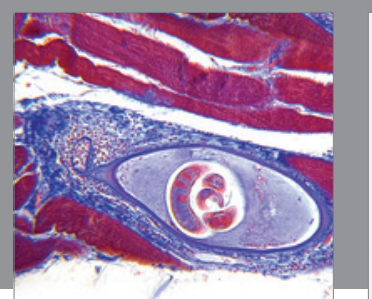

Gastroenterology Research and Practice

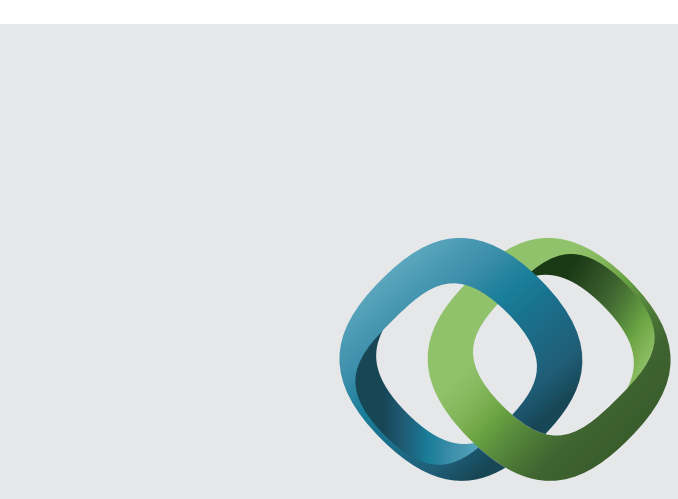

\section{Hindawi}

Submit your manuscripts at

http://www.hindawi.com
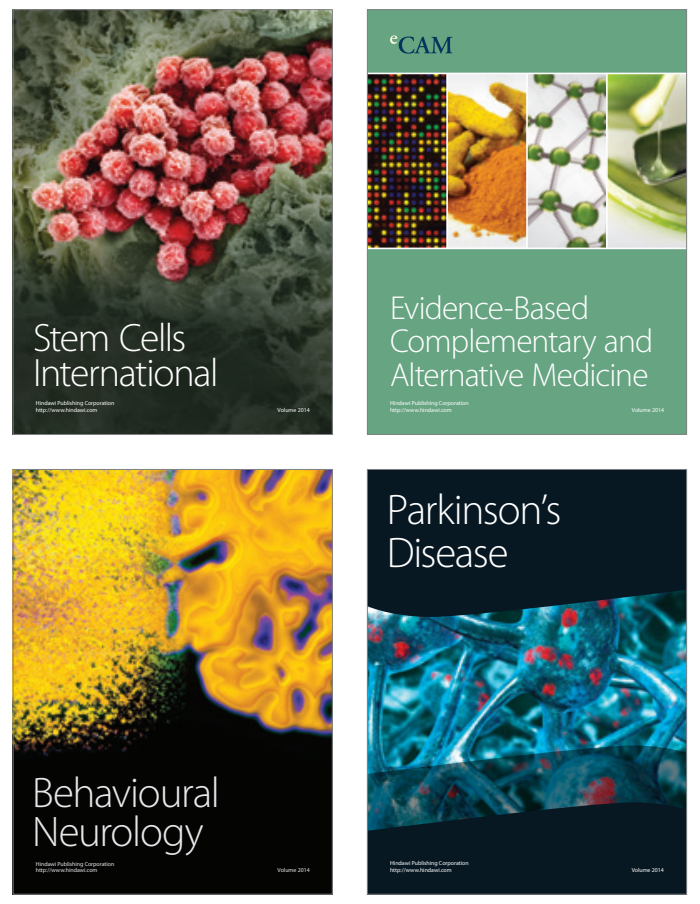
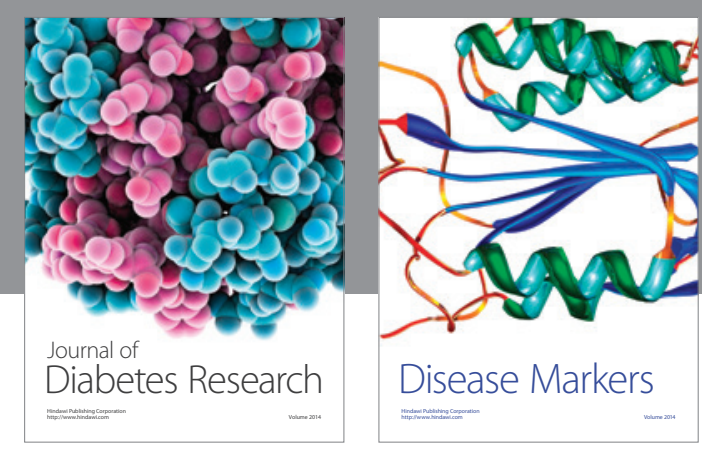

Disease Markers
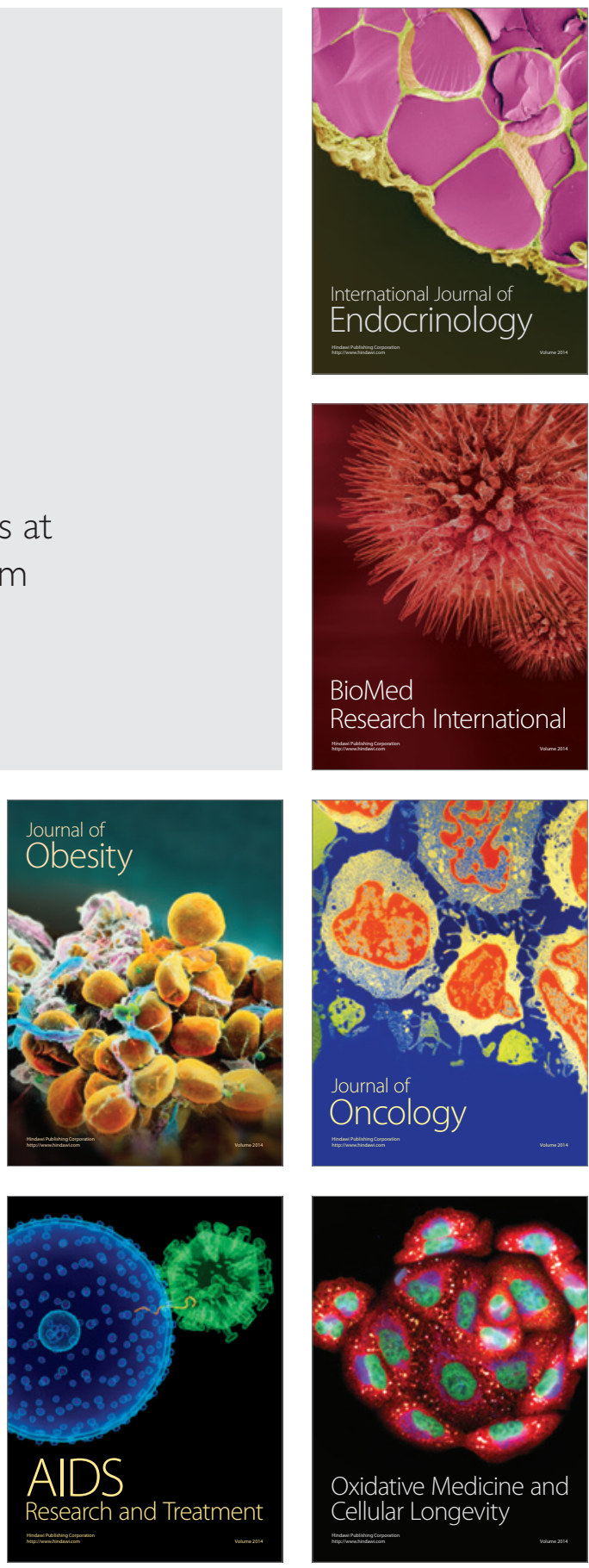